\title{
The Analysis of Students' Ability in Thinking Based on Cognitive Learning Style
}

\section{Dwi Purnomo}

Dr., coresponding author, Department of Mathematics Education, IKIP Budi Utomo, Jalan Simpang Arjuno No.14B Malang-Indonesia,dwi2purnomo@yahoo.co.id

\section{Susilo Bekti}

Dr., Department of Mathematics Education, IKIP Budi Utomo, Jalan Simpang Arjuno No. 14B Malang-Indonesia, susilobekti2006@gmail.com

\section{Yunis Sulistyorini}

Department of Mathematics Education, IKIP Budi Utomo, Jalan Simpang Arjuno No. 14B MalangIndonesia, yunis.sulistyorini@gmail.com

\section{Siti Napfiah}

Department of Mathematics Education, IKIP Budi Utomo, Jalan Simpang Arjuno No. 14B MalangIndonesia,napfiahsiti@gmail.com

\begin{abstract}
This research was conducted in October-November 2019 and aims to describe students' abilities in critical, creative, communicative, and collaborative thinking based on cognitive learning style. To make known the achievement of the objectives of the study, research subjects have been chosen that have a cognitive style in learning. Cognitive style is individual style in thinking, perception and remembering information influencing someone's learning and interacting in class as well as referencing influencing in accordance with the environment, social interaction, and personal characteristics. After having a lecture, 35 second year mathematics students at "Budi Utomo" Institute of Teacher Training and Education who are taking Calculus as a research subject were given questionnaire of the group embedded figure test (GEFT). The Questionnaire consisting of the indicators of critical, creative, communicative, and collaborative thinking skills. The score of each single subject of study is the data of the study in the form of qualitative descriptive. Critical thinking skills are categorized into 5 levels, namely very critical, critical, moderately critical, uncritical and very uncritical. Likewise, the ability to think creatively, communicatively and collaboratively are categorized into 5 levels. The final results of the research show statistically that the thinking skills of the research subjects are in the critical category, creative enough, very communicative and collaborative.
\end{abstract}

Keywords: thinking ability, cognitive style, field independent, creativity, learning

\section{INTRODUCTION}

The students' ability to think critically, creatively, communicatively, and collaboratively (4C) are needed in the millenial era very much. The ability needed in $21^{\text {nd }}$ are critical, creative, communicative and collaborative (Victor, 2015) and in the global era the student wants to be competent in a community, she/he needs a special skill consists of ability in communication, creation, critical thinking, and collabration (Roekel. 2014). Based on the opinion, for the time being, students are expected to own the ability to master knowledge, metacognitive skill, critical and creative thinking, as

Citation: Purnomo, D., Bekti, S., Sulistyorini, Y., \& Napfiah, S. (2021). The analysis of students' ability in thinking based on cognitive learning style. Anatolian Journal of Education, 6(2), 13-26. https://doi.org/10.29333/aje.2021.622a 
well as being able to communicate and collaborate effectively. High metacognitive skill can increase students' ability to solve mathematics problem (Purnomo \& Bekti, 2017).

As the material of learning at schools, the implementation of mathematics will be better if the teacher always pays attention to the students' critical, creative, communicative and collaborative thinking ability. In particular, the mathematics learning should pay attention to creative, critical, communicative, and collaborative aspect, (Sulistyorini \& Napfiah, 2019) So, it is a must for all the students own critical, creative, communicative and collaborative thinking ability and thinking critically as skills needed by everyone to cope with the $21^{\text {st }}$ century (Redhana, 2019). On the other side, the students in $21^{\text {st }}$ century need to stimulate to own the critical thinking ability in order to be able to solve the complex problems (Praherdhiono, et al. 2019). As the opinion of Preherdhiono, the teachers need to understand the process of students' critical thinking to solve problems. In particular, the critical thinking relates to mathematics. Critical thinking can be trained through studying mathematics and mathematics can be understood through critical thinking and everyone owns the ability to increase and improve his/her critical thinking ability when learning mathematics. (Mahmuzah, 2015).

There are some definitions of critical thinking. Critical thinking is a cognitive activity relating to mind (Cotrell, 2005). It is one of instruments used to solve problem in daily life. It consists of logical reasoning, interpretate, analyze and evaluate information to make a valid and believable decision or conclusion (Chukwuyyenum, 2013). The indicators of critical thinking ability are using inductive or deductive reasoning, analizing linkage every part to obtain a complex system, analyzing and evaluating the facts, making a conclusion based on result of analysis, and solving the problem which cannot be solved by using neither conventional nor innovative one. Other than that, creative thinking ability is also needed in globalisation era (Maharani, 2014).

Creative thinking is needed to cope with the challence of globalisation era as the complexity level of the problem is getting higher at all aspects of modern life. Critical and creative thinking are closely related (Rohmad, et al. 2018). To be able to solve problem, someone has to know the relevant rule based on critical and creative thinking aspects. Beside those two opinions, the difficulty of thinking critically can disturb someone to think creatively and mathematically. The improvement of creative thinking abilities needed in mathematics learning very much. The improvement of mathematical creativity at school must be preceeded from mathematics teacher (Gregoire, 2016), to express that creativity must be applied mathematics activity. The application of creative activity in mathematics learning has a positive effect to high level thinking ability (Nadjafikhah \& Yaftian, 2013). Creative thinking has some definitions. Creative thinking is a way to produce new ideas through creative activity (Maharani, 2014). Creative thinking is an abstract, brave, discipline organized power which appear as the consequence of the environmental condition that becomes a booster of a person to do something (As'ari, 2016). Creative thinking ability can be seen from fluency, flexibility, and novelty aspects. In the research, the indicator of creative thinking ability consists of giving some answers and true (fluency), applying some techniques of problem solving and true (flexibility), and giving different answers (novelty) (Jagom, 2015; Iswanti et al. 2016; Muthaharah et al. 2018).

Mathematical communication is important because it is not only a thinking organ, but also is an organ to transfer mind and idea clearly, accurately, and shortly (Yuniarti, 2014). If the students' communicative ability is getting higher, the result of mathematics learning will increase (Vale \& Barbosa, 2017; Yuniar, et al. 2017). The indicators of communicative ability are able to express idea either oral or written, able to express idea and mind effectively, able to communicate using appropriate and clear language, able to communicate for multi-purposes (i.e. inform, instruct, motivate, or invite), and able use terms, symbols, and structures for modeling mathematics problems. The indicators of communicative ability in the research consists of the ability to express mind and idea orally and 
effectively, the ability to express terms, symbols, and structures for modeling mathematicas problems (NCTM, 2000),

The process of collaborative thinking emphasizes to cooperation, appreciation, responsibility, and tolerant (Apriono, 2013). Collaborative learning emphasizes to 1) practical realization, collaborative activity needed to face real life, and 2) develop the awareness of social interaction to realize meaningful learning (Zubaidah, 2010). Collaborative learning can increase students' understanding concept (Mirza, 2014). While Laal \& Ghodsi says that learning result of collaborative learning is better than individual learning (Laal \& Ghodsi, 2012).

Based on the result of the observation of the students at "Budi Utomo" Institute of Teacher Training and Education Malang, many students have not given the reasons of the answers. It shows that many students have not showed the critical thinking ability yet. Many students are difficult to express their new ideas, give different answers, and apply ways to solve problem. It shows that most of the students have not showed their creative thinking ability. There are many students express their ideas uneffectively, use a language unappropriately, and are not able to arrange mathemetics modeling to solve problem. So, it is known that many students do not have good communicative ability yet. There are many students hard to cooperate to finish group work. It shows that students cannot show their collaborative ability.

Some researches on the ability of students to think has been done, research and analysis of critical thinking in students with cognitive style of learning (Rifqiyana \& Susilo, 2016; Firdausi et al., 2018), reserach on creative thinking skills based on student learning styles (Wijaya, et al.,. 2016), analysis of communicative thinking skills through the 4C model (Pertiwi \& Susilo, 2014), and reserch and analysis of communicative thinking skills using the 4C model based on students personality (Achir et al., 2017. Based on the cases above, it needs to carry out the study to analyse the students' critical, creative, communicative and collaborative thinking ability in mathematics learning activity. The objective of the study is to describe students critial, creative, comunicative, and collaborative thinking ability, especially the students having cognitive style field independent. The study is limited to explore deeply how thinking ability of students having ccognitive style field independent is. The students having cognitive style field independent is very unique because tending to be independent in learning.That's why, researchers want to explore deeply not only from the aspect of cognitive, i.e. critical and creative thinking ability but also involving social aspect, i.e. communicative and collaborative thinking ability.

\section{METHOD}

This is a qualitative research involving 35 second year mathematics students at "Budi Utomo" Institute of Teacher Training and Education Malang who are currently taking Calculus and have an independent field cognitive learning style. The choice of Calculus courses, because Calculus is the basis and requirement for the next subjects. The main instrument in the research is a questionnaire called the embedded figure test (GEFT) to select someone having cognitive style field independent or field dependent, problem solving questions, assessment rubric of critical, creative, communicative, and collaborative thinking. The procedure of the study covers preparation and operation phases. At the preparation phase, researchers make the instrument of the study then operation phase be done. The phases of the study are: (1) carry out Calculus learning on the large of flat area, (2) give mathematics problems to the subject of the study, (3) give a questionnaire to 35 students who were taking Calculus courses and the subjects of reserach who had been selected of having cognitive style field independent, (4) choose 3 subjects of the study having cognitive style field independent, (5) analyze critical, creative, communicative and collaborative thinking ability based on mathematics problem and the result of questionnaire GEFT given, (6) make a conclusion of the result of the study by determining the subject of the study thinking model having cognitive style field independent.

Anatolian Journal of Education, October $2021 \bullet$ Vol.6, No.2 
Based on the indicators of each student's ability to think critically, creatively, communicatively and collaboratively, the researchers set an assessment rubric for each of the abilities to think critically, creatively, communicatively, and collaboratively. The assessment rubric made describes each indicator in the form of student activities. Student activities as a description of the achievement indicators were given a score of $3,2,1$, and 0 . The assessment rubric and description of each indicator of students' abilities in critical, creative, communicative and collaborative thinking can be explained as follows. Determination of the score $3,2,1,0$ on the assessment rubric aims to determine at what levels the thinking ability of the research subjects after knowing all the scores obtained by the subjects of research and their averages. The averages scores were obtained by the subjects and convert being to a table of categories of students' thinking ability which consists of 5 levels

\section{Critical Thinking Ability Indicators}

The ability to think critically consists of 4 indicators, including: 1) providing a variety of reasoning in accordance with the existing situation (A1) are described in the activities: able to give various reasoning suitable with the problem given (A1.1, score 3), able to give various reasoning but not suitable with the problem given (A1.2, score 2), able to give a reasoning suitable with the problem given (A1.3, score 1), and unable to give various reasoning suitable with the problem given (A1.4, score 0 ); 2) providing a relationship between information and arguments (A2), are desribed in activities: able to give alternative and describe the relationship between argument and information given and it is true (A2.1, score 3), able to give alternative and describe the relationship between alternative and information given and it is true (A2.2, score 2), able to give alternative but unable to describe the relationship between alternative and information given and it is true (A2.3, score 1), and unable to give alternative and describe the relationship between alternative and information given and it is true (A2.4, score 0$)$; 3) providing various perspectives to get the best solution (A3), described in the activities: able to identify problem from various points of view and it is true (A3.1, score 3 ), able to identify problem from various points of view and it is wrong (A3.2, score 2), able to identify problem limited to one points of view (A3.3, score 1) and unable to identify problem from various points of view and it is true (A3.4, score 0$)$; 4) analyzing and evaluate the main alternative choices (A4) are described in the activities: able to analyze and evaluate main alternative choice to solve problem correctly (A4.1, score 3), able to analyze and evaluate main alternative choice to solve problem but it is wrong (A4.2, score 2), able to analyze main alternative choice without evaluating (A4.3, score 1), and unable to analyze and evaluate main alternative choice to solve problem (A4.4, score 0).

\section{Creative Thinking Ability}

The ability to think creatively consists of 3 indicators, including: 1) giving some answers and true (fluency) (B1) are described in the activities: able to obtain various answers and they are true (B1.1, score 3), able to produce many answers but not yet correct to solve problems (B1.2, score 2), able to obtain one answer only to solve problem (B1.3, score 1), and unable to obtain one answer to solve problem (B1.4, score 0); 2) applying some techniques of problem solving and true (flexibility) (B2) are described in the activities: able to use more than one techniques of problem solving and they are true (B2.1, score 3), able to use more than one techniques of problem solving and they are wrong (B2.2, score 2), able to use one technique of problem solving and it is true (B2.3, score 1), and unable to use one technique of problem solving (B2.4, score 0); (3) giving different answers (novelty) (B3) are described in the activities: able to create new idea by his/her own way and it is suitable with the contect of the problem solved (B3.1, score 3), Able to create new idea by his/her own way but it is not suitable with the contect of the problem solved (B3.2, score 2), Able to create new idea but it is not her/his own way (B3.3, score 1), and unable to create new idea by his/her own way and it is suitable with the contect of the problem solved (B3.4, score 0$)$. 


\section{Communicative Thinking Ability}

The ability to think comucatively consists of 3 indicators, including: 1) expressing oral ideas effectively (C1) are described in activities: able to express oral idea appropriately in a time duration determined (C1.1, score 3), able to express oral idea appropriately accurately but need longer time to express ( $\mathrm{C} 1.2$, score 2), able to express oral idea appropriately but unaccurate in time duration determined (C1.3, score 1), unable to express oral idea appropriately accurately and need long time. in a time duration determined $(\mathrm{C} 1.4$, score 0$) ; 2)$ expressing written ideas effectively $(\mathrm{C} 2)$ are described in indicators: able to express written idea appropriately in a time duration determined (C2.1, score 3), able to express written idea appropriately but need longer time to express (C2.2, score 2), able to express written idea but it is unappropriate in time duration determined (C2.3, score 1), and unable to express idea appropriately and need long time (C2.4, score 0); 3 ) using terms, symbols and structures for modeling mathematics problems (C3) are described in activities: able to use terms, symbols, or structures to model mathematic problem correctly (C3.1, score 3), able to use terms, symbols, or structures to model mathematic problem but most of them are correct (C3.2, score 2), able to use terms, symbols, or structures to model mathematic problem but little amount of them are correct (C3.3, score 1), and unable to use terms, symbols, or structures to model mathematic problem correctly (C3.4, score 0).

\section{Collaborative Thinking Ability}

The ability to think collaborative consists of 3 indicators, including: 1) able to appreciate others' opinion (D1) are described in an activities: mable to appreciate every other's opinion (D1.1, score 3), able to appreciate most of other's opinion (D1.2, score 2), able to appreciate little amount of other's opinion (D1.3, score 1), and unable to appreciate every other's opinion (D1.4, score 0 ); 2) able to show the flexibility to be helpful (D2) are described in the activities: want to help the person who needs a help (D2.1, score 3), want to help most people who need help (D2.2, score 2 ), want to help little amount of people who need a help (D2.3, score 1), and does not want to help the person who needs a help (D2.4, score 0); 3) able to carry out group's duty (D3) are described in the activities: able to carry out every duty as his/her responsibility (D3.1, score 3), able to carry out most of duties as his/her responsibility (D3.2, score 2 ), able to carry out little amount of duties as his/her responsibility (D3.3, score 1), and unable to carry out most of duties as his/her responsibility (D3.4, score 0)

\section{FINDINGS}

To measure the process of students thinking, the subject of study were given mathematic problem, as follows: 1) chose the distribution $n$ to estimate the real value of field area below the curve using amount of Riemann. Explained choice ofreason $n$ to estimate the real value of field area below the curve; 2) determined the real field area. Explained and how to determine field area below the curve. 


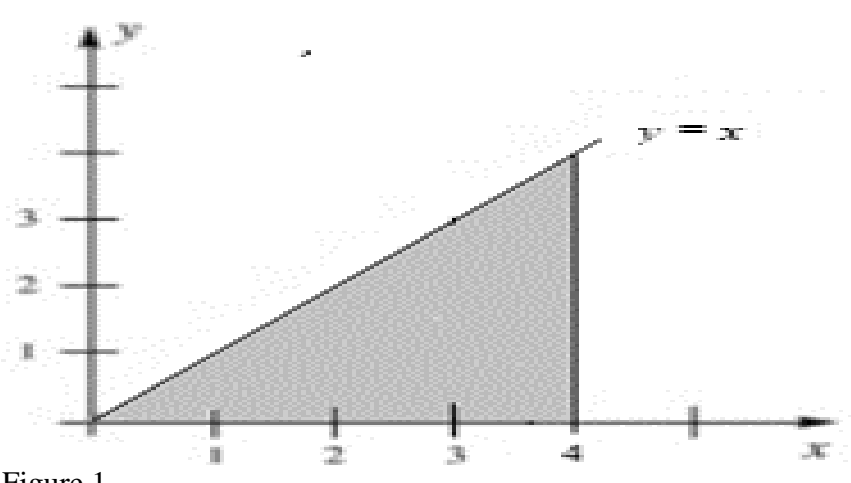

Figure 1

Field area below the curve

\section{Subject-1 (S-1)}

For the first problem, the subject could determine the distributon $n$ and explained the reason of determination of $n$. The subject gave three choices $n$, i.e. n2, n4 and n8. For each $\mathrm{n}$ and the subject gave three alternatives by using right Riemann, left Riemann, and middle point. The reason of the choice was to give the comparation among those three alternatives. The subject could determine partition of each interval $\mathrm{n} 2, \mathrm{n} 4$ and $\mathrm{n} 8$ so that getting the width and lenght of each of square. Next, counted the amount of Riemann based on the partition to estimate the field area below the curve. At the last answer, the subject explained that the best alternative to estimate the field area below the curve used centre point of Riemann.

While in the second problem, the subject explained that the field area below the curve could be obtained by counting the area of triangle. It was because field area below the curve was triangle, especially right triangle. The subject was able to determine triagular base and height as well as explained the reason of identification part of curve and then counted the area of triangle correctly to determine the real area below curve.

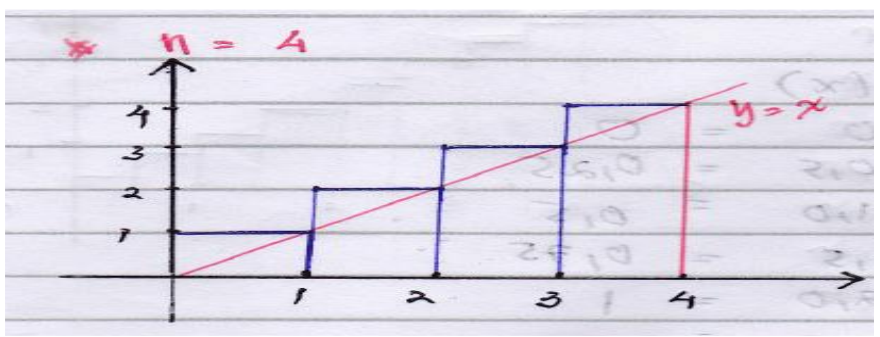

Figure 2

Mathematic problem solving of subject-1

\section{Subject-2 (S-2)}

For the first problem, subject chose $n=6$ and explained that the reason of choosing $n$ because $n=6$ is better for estimating field area below curve than $n=2$ as given at the discussion before. Subject determined partition of every interval $n=6$ that is $1-1.5,1,5-2.0,2,0-2.5,2.5-3.0,3.0-3.5$, and 3,5-4.0 which show that the subject made a mistake in determine partition because did not pay attention interval width for $n=6$ and interval 0 until 1.Then, subject counted Riemann using the partition to estimate the field area below the curve and gave alternative in estimating field area below the curve using a certain integral definition. But when counting Riemann, subject made a mistake sothat the real 
estimation of the area is wrong. At the end answer, subject was able to explain that amount of Riemann relates to the field area below curve by consedering a certain integral definition.

For the second problem, subject explained that field area below the curve could be obtained by counting the area of right triangle. Subject could determine the base and hight of triangle and gave the explanation about the reason of identication of curve part.

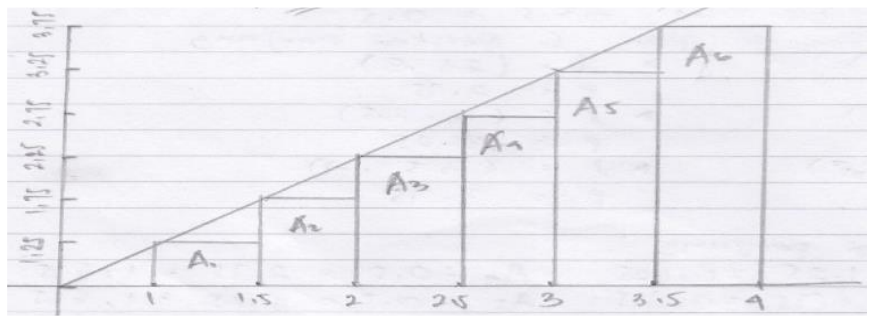

Figure 3

Mathematic problem solving of subject-2

\section{Subject-3 (S-3)}

Subject chose $n=8$ and explained the reason of choosing $n$, i.e $n=8$ is better in estimating field area below curve than $n=2$ given at the previous learning. Subject could determine partition every interval with n-8. Next, Subject counted the amount of Riemann using partition at steps before and explained relationship between amount of Riemann and field are below curve, that amount of Riemann can be used to estimate the real field area.

For the second problem, Subject explained that field area below curve can be obtained using centain integral way. Subject was able to determine formula to apply certain integral and counted certain integral correctly. Sothat, subject gave alternative to determine field area below curve using certain intergral.

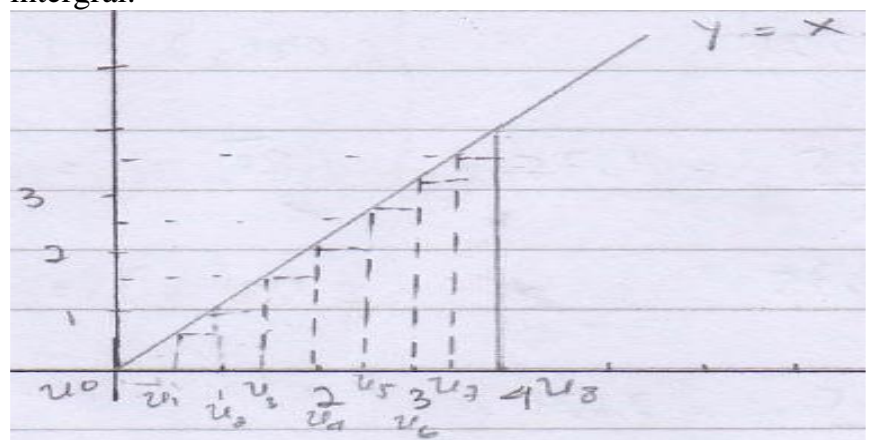

Figure 4

Mathematics problem solving of subject-3

The three subjects chosen, i.e. S-1, S-2, and S-3, after finishing lerning and being given questionnaire group embedded figure test (GEFT) for each indicator of critical, creative, communicative, and collaborative thinking ability have result and score that can be seen at Table 1, 2, 3, and 4. 
Table 1

Critical thinking ability of the subject

\begin{tabular}{llll}
\hline \multirow{2}{*}{ Indicator } & Appearing Indicator/Score & & \\
\cline { 2 - 4 } & $\mathrm{S}-1$ & $\mathrm{~S}-2$ & $\mathrm{~S}-3$ \\
\hline $\mathrm{A} 1$ & $\mathrm{~A} 1.1 / 3$ & $\mathrm{~A} 1.3 / 1$ & $\mathrm{~A} 1.3 / 1$ \\
\hline $\mathrm{A} 2$ & $\mathrm{~A} 2.1 / 3$ & $\mathrm{~A} 2.1 / 3$ & $\mathrm{~A} 2.1 / 3$ \\
\hline $\mathrm{A} 3$ & $\mathrm{~A} 3.1 / 3$ & $\mathrm{~A} 3.3 / 1$ & $\mathrm{~A} 3.3 / 3$ \\
\hline A4 & $\mathrm{A} 4.1 / 3$ & $\mathrm{~A} 4.2 / 2$ & $\mathrm{~A} 4.2 / 1$ \\
\hline Average & 3 & 1,75 & 2 \\
\hline
\end{tabular}

Based on analysis summaried at Table 1, it can be concluded that subject-1 is categorized very critical, subject-2 is categoried enough critical and subject-3 is categorized critical. From the average score of each subject, it can be obtained average score of those three subjects is 2,25 So, the average ability of those three subjects who are cognitive style field independent are categorized critical.

Table 2

Creative thinking ability of the subject

\begin{tabular}{llll}
\hline \multirow{2}{*}{ Indicator } & \multicolumn{2}{l}{ Appearing Indicator/Score } & \\
\cline { 2 - 4 } & $\mathrm{S}-1$ & $\mathrm{~S}-2$ & $\mathrm{~S}-3$ \\
\hline $\mathrm{B} 1$ & $\mathrm{~B} 1.1 / 3$ & $\mathrm{~B} 1.4 / 0$ & $\mathrm{~B} 1.3 / 1$ \\
\hline $\mathrm{B} 2$ & $\mathrm{~B} 2.1 / 3$ & $\mathrm{~B} 2.4 / 0$ & $\mathrm{~B} 2.4 / 0$ \\
\hline $\mathrm{B} 3$ & $\mathrm{~B} 3.1 / 3$ & $\mathrm{~B} 3 . .4 / 0$ & $\mathrm{~B} 3.3 / 1$ \\
\hline Average & 3 & 0 & 0,67 \\
\hline
\end{tabular}

Based on analysis summaried at table 2, it can be concluded that subject-1 is catgorized very creative, subject- 2 is categorized very creative, and subject- 3 is categorized creative. From the average score of each subject is obtained the average score 1,22 . So, the average ability of those three subjects who are cognitive style field independent are categorized enough creative.

Table 3

Communicative thinking ability of the subject

\begin{tabular}{llll}
\hline \multirow{2}{*}{ Indicator } & \multicolumn{2}{l}{ Appearing Indicator/Score } & \\
\cline { 2 - 4 } & $\mathrm{S}-1$ & $\mathrm{~S}-2$ & $\mathrm{~S}-3$ \\
\hline $\mathrm{C} 1$ & $\mathrm{C} 1.1 / 3$ & $\mathrm{C} 1.2 / 2$ & $\mathrm{C} 1.3 / 1$ \\
\hline $\mathrm{C} 2$ & $\mathrm{C} 2.1 / 3$ & $\mathrm{C} 2.1 / 3$ & $\mathrm{C} 2.1 / 3$ \\
\hline $\mathrm{C} 3$ & $\mathrm{C} 3.1 / 3$ & $\mathrm{C} 3.1 / 3$ & $\mathrm{C} 3.1 / 3$ \\
\hline Average & 3 & 2,67 & 2.3 \\
\hline
\end{tabular}

Based on analysis summaried at table 3 , it can be concluded that subject- 1 is categorized very very communictive, subject-2 is categorized very communicative and subject-3 is categorized communicative. From the average score of each subject is obtained the average score of those three subjects 2,67 . So, the average ability of those three subjects who are cognitive style field independent is categorized very communicative. 
Table 4

Communicative thinking ability of the subject

\begin{tabular}{llll}
\hline \multirow{2}{*}{ Indicator } & \multicolumn{2}{l}{ Appearing Indicator/ Score } & \\
\cline { 2 - 4 } & $\mathrm{S}-1$ & $\mathrm{~S}-2$ & $\mathrm{~S}-3$ \\
\hline $\mathrm{D} 1$ & $\mathrm{D} 1.3 / 1$ & $\mathrm{D} 1.3 / 1$ & $\mathrm{D} 1.3 / 1$ \\
\hline $\mathrm{D} 2$ & $\mathrm{D} 2.2 / 2$ & $\mathrm{D} 2.2 / 2$ & $\mathrm{D} 2.2 / 2$ \\
\hline $\mathrm{D} 3$ & $\mathrm{D} 1.3 / 3$ & $\mathrm{D} 1.1 / 3$ & $\mathrm{D} 1.3 / 3$ \\
\hline Average & 2 & 2 & 2 \\
\hline
\end{tabular}

Based on analysis summaried at Table 4, it is concluded that subject-1 is categorized very very collaborative, subject- 2 is categorized collaborative and subject- 3 is categorized collaborative. From the average score each of the subject is obtained that the average score for those three subjects is 2 . So, the average of ability of three subjects which are cognitive field independent are categorized collaborative.

\section{CONCLUSION, DISCUSSION AND SUGGESTIONS}

The result of the study shows that generally the average cognitive field independent students' thinking ability are in the category critical, enough creative, very communicative and collaborative. If being seen individually, students cognitive style field independent have diverse critical and creative thinking abilities and have similar communicative and collaborative abilities. The students having cognitive style field independent who tend to be independent inlearning are able to communicate and collaborate well.

Based on test and interview and if being seen from the critical thinking ability, subject-1 was able to give various reasoning as the problem given. It was showed by various choices $n$ followed by the reason suitable with the problem given. Subject-1 was able to identify problem by sharing point of view and true. It was showed when subject- 1 did not only consider distribution of value $n$ in estimating the real value of field below curve. Subject-1 considered type of amount Riemann used, i.e. right, left and middle Riemann. Based on the choice $n$ and type of Riemann, finally subject 1 was able to conclude that the best estimation $\mathrm{n}$ determine field area below the curve was by using middle Riemann. It was powered by solving subject of problem 2 which the subject explained that the real area equal to counting field area of right triangle as observed by subject in figure 1 . It showed that subject-1 was able to find out the relationship between argument and given information as well as analyze and evaluate main alternative choice.

If being seen from the ability of creative thinking, Subject 1 fulfilled the indicators fluency, flexibility and novelty. Fluency indicator is subject-1 was able to give many answers and they are true. It is showed by the subject chooses more than $n$ in estimating real area, i.e. $\mathrm{n}=2, \mathrm{n}=8$, and $\mathrm{n}=8$. Flexibility indicator is subject-1 was able to use more than one techniques of problem solving and they are true. It is showed when subject estimates the real area using three techniques Riemann, i.e. right, left, and middle. While novelty indicator is able to creat new idea by her/his own way and suitable with the context of the problem solved. It is showed by solving problem 2 using area of triangle rather than applying integral which is in previous discussion.

Based on the result of the test and observation during learning, communicative ability of subject 1 when expressing idea orally, he/she could express exactly but needs rather long time. In expressing witten idea, subject- 1 is able to expresses it exactly as the time given. Beside that, Subject 1 could solve the problem by modeling mathematic problem using terms, symbols, or structure correctly. Based on the result of test and interview, being seen from the critical thinking ability, subject- 2 could give one reasoning as the problem given only. It is showed by choice $n=6$ followed by a reason that $n=6$ is better in estimating the field area below curve than $n=2$ as material before. It is because the 
bigger $n$, it will more closely to the real value of field area below curve looked for. Subject- 2 could identify the problem but it is limited to one point of view.It is showed when subject-2 considered middle Riemann only to estimate the real area. Subject- 2 choose middle Riemann based on previous experience in solving similar problem. At the problem 2, Subject explained that the real area is same with counting intergral of function $f(x)=x$ with lower limit $x=1$ and upper limit $x=4$. The mistake of deteminition of lower and upper limit causes the real value is not true. The final part of the answer, subject-2 emphasized relationshpip between amount of Riemann and the real area by counting infinity limit of amount of Riemann as acertain integral definition. So, subject-2 was said to be able to find out relationshp between argument and information given, analyze and evaluate main alternative choice but wrong.

If being seen the creative thinking ability, subject-2 is said not fulfill fluency, flexibility and novelty indicators yet. Fluency indicator, subject-2 was unable to give an answer and fledxibility indicator, subject-2 was unable to use a problem solving technique. It is showed by choice $\mathrm{n}$ which is only one to estimate the real area, $n=6$ using middle Riemann technique only and result the wrong calculation because the fault in partition determination. Novelty indicator, subject- 2 was able to create new idea by self-way and gives wrong answer. It is showed by solving praoblem 2 using application integral as the previous material and because of making mistake in determinition of lower and upper limit of integral, the problem solving given by subject -2 was also wrong. Based on the result of the test and observationduring learning, communicative ability of subject-2, i.e. when the lecturer asked everyone to express orally idea, subject- 2 tended not to express it but when being appointed, subject 2 could do it correctly but needed a long time to express it. In expressing written idea, subject- 2 could express it correctly as the time given. Beside that, subject-2 could solve problem by modeling mathematic problemusing terms, symbols, or structures correctly. Based on the result of observation during learning, it is known that subject-2 was able to appreciate others' opinion but only little amount, willing to help most people, able to carry out every duty that become group's responsible. Based on the result of test and interview, if being seen the critical thinking ability, subject- 3 was able to give one reasoning as the roblem given. It is showed by choice $n=8$ followed by the reason that $n=8$ is better in estimation field are below curve than $\mathrm{n}=2$ as given at previous learning because being bigger $n$, it will be closer to the real value of field area below curve. Subject-3 was able to identify problem but limit to one point of view only. It is showed when subject-3 considered middle Riemann in estimating the real area. Subject chose middle Riemann based on last experience in solving similar problem. For the second problem, Subject explained that the real area is counting certain integral of function $f(x)=x$ with lower limit $x=0$ and upper limit $x=4$. So, subject-3 is said to be able to find out the relationship between argument and information given, analyze and evaluate main alternative choice.

If being seen from the creative thinking ability, subject-3 is said not fully fulfill fluency, flexibility and novelty indicators. Fluency indicator, subject-3 was able to give one answer only. And in flexibility indicator, subject-3 was able to use one technique of problem solving.It is showed by choice $n$ that is only one in estimating the real area, i.e. $n=8$ us middle Riemann technique and produce the correct calculation. Novelty indicator, i.e. Subject-3 was not able to create new idea by him/herself. It is showed by solving problem 2 by applying certain integral as given in the last material, not other way determined by the Subject.

Based on the results of the S-3 test which can be seen from the value after the end of lecture activities and the results of the researchers' observations on S-3 during lecture activities which can be seen from the final observation sheet of communicative ability subject-3, as well as when the researcher asked everyone to express ideas verbally, subject-3 often expressed their ideas sometimes are not appropriate. And in expressing ideas within the time duration given, his sentences spoken are less accurate. In expressing written ideas, subject-3 was able to express written ideas accurately as the time given. Beside that, subject- 3 was able to solve problem by modeling mathematics problem using

Anatolian Journal of Education, October 2021 • Vol.6, No.2 
terms, symbols or structures correctly. Based on the result of the test and obsevation during learning, it is known that subject-3 was able to appreciate other opinion but only little amount, willing to help most of people, able to carry out every duty of group's responsible.

For the whole, subject-1 is categorized very critical, very creative, very communicative, and collaborative. Subject-2 is categorized enough critical, not creative, very communicative, and collaborative. While subject-3 has critical ability, less creative, communicative, and collaborative. So, those three subjects have diverse critical and creative thinking abilities. While communicative and collaborative abilities tend to same.

The explanation above provides an explanation of the results of the study as follows.

1. Someone critical and creative thinking ability is not only influenced by the cognitive style. It is showed by the result of the study which shows that the three subjects with same cognitive style, i.e. field independent, have diverse critical and creative thinking abilities, from enough critical to very critical and from less creative to very creative. Whereas being known that field independent has better performance inassignment needed to finish logically and tends to be able to do selfmotivation well in mathematics (Sharma \& Ranjan, 2018). Sothat, strategic learning step need to apply to improve students critical and creative thinking ability remembering students have potency to be able to think logically well.

2. Increasing critical and creative thinking ability is still needed to be one of the attention focus in learning. Although the average of the three subjects are in the category critical and enough creative but the result of the study shows that there is a subject still enough critical even not creative. The improvement is not only limited to field independent student but also field dependent student. It is because of the different cognitive style own by someone does not make he/she better than the other. (Sharma \& Ranjan, 2018).

3. High mathematics academical ability is not necessarily be the reference that a person has high critical and creative ability. It is known from the fact that the three subjects who have high academic ability own very diverse critical and creative thinking ability. So that, based on the second finding the improvement of critical and creative thinking ability still become attention focus in learning mathematics. Solving the problem is the step to be done. A person who solves the problem will think that the problem given is different as usual problem given before. Sothat, it is needed to give a chance to improve other mathematic creativity and ability (Ayllon et al., 2016) Problem based learning can also improve someone's critical thinking ability. (Firdaus, et al., 2015) and specially opened problem can be considered to improve creative thinking ability (Maharani, 2014).

4. Student owns cognitive style field independent who tends to independent in learning can communicate and collaborate well. Thinking critically and creatively involve cognitive aspects while communicative and collaborative involve cognitive and social aspects. So, although a person has cognitive style field independent is independent, still having social aspect well in learning.

Based on the result and findings obtained, the reserch can be done furthemore to study the relationship between critical and creative thinking ability. It is because the result of the study shows that students who are very critical is also very creative, students who are less critical is not creative, and students who are enough critical are less creative. Beside that, it can also be explored how 4C ability for studentscognitive style field dependent is. While suggestion given by the researchers is that learning should be designed in order to be able to accomodate whole students' ability to improve $4 \mathrm{C}$ which is needed in daily life very much. 
This research has resulted in 4 types of students' thinking skills in solving problems in mathematics based on their cognitive learning styles, namely critical thinking skills, creative enough, highly communicative and collaborative. For further research, it is necessary to see how the relationship between the thinking abilities of each student is not only based on their learning style but can be related to the learning model and methods used or other factors in learning mathematics in the classroom. In addition, research subjects can also be developed in a group with more students.

\section{REFERENCES}

Achir, Y. S., Usodo, B., \& Retiawan, R. (2017). Analisis kemampuan komunikasi matematis siswa dalam pemecahanan masalah matematika pada materi sistem persamaan linear (SPLDV) ditinjau dari gaya kognitif. Paedagogia, 20(1). https://doi.org/10.20961/paedagogia.v20i1.16600

Apriono, D. (2013). Pembelajaran kolaboratif: Suatu landasan untuk membangun kebersamaan dan keterampilan kerjasama. Diklus, XVII(1).

As'ari, A. (2016). Variasi konstruk dalam pembelajaran matematika. Malang: CV Bintang Sejahtera.

Chukwuyenum, A. N. (2013). Impact of critical thinking on performance in mathematics among senior secondary school students in lagos state. IOSR Journal of Research \& Method in Education (IOSRJRME), 3(5), 18-25. https://doi.org/https://doi.org/10.9790/7388-0351825

Cottrell, S. (2005). Critical thingking skills: Developing effective analysis and argument. Palgrave Macmillan.

Firdausi, Y. N., Asikin, M., \& Wuryanto, W. (2018). Analisis kemampuan berpikir kreatif ditinjau dari gaya belajar. PRISMA, Prosiding Seminar Nasional Matematika, 1, 239-247.

Gregoire, J. (2016). Understanding creativity in mathematic for improving mathematica education. Journal of Cognitive Education and Psychology, 15(1), 24-36.

Iswanti, P., Riyadi., \& Usodo, B. (2016). Analisis tingkat kemampuan berpikir kreatif peserta didik dalam memecahkan masalah geometri ditinjau dari gaya belajar. Jurnal Elektronik Pembelajaran Matematika, 4(6), 632-640.

Jagom, Y. O. (2015). Kreativitas siswa SMP dalam menyelesaikan masalah geometri berdasarkan gaya belajar visual-spatial dan auditory-sequential. Math Didactic: Jurnal Pendidikan Matematika, 1(3), 176-190. https://doi.org/10.33654/ math.v1i3.18

Laal, M., \& Ghodsi, S. M. (2012). Benefits of collaborative learning. In Procedia - Social and Behavioral Sciences. https://doi.org/10.1016/j.sbspro.2011.12.091

Maharani, H. R. (2014). Creative Thinking in mathematics: Are we able to solve mathematical problems in a variety of way? In International Conference on Mathematics, Science, and Education. Semarang.

Mahmuzah, R. (2015). Peningkatan kemampuan berpikir kritis matematis siswa smp melalui pendekatan problem posing. Jurnal Peluang, 4(1), 64-72.

Muthaharah, Y. A., Kriswandani, \& Prihatnani, E. (2018). Analisis kemampuan berpikir kreatif matematis siswa smp dalam menyelesaikan soal bangun ruang sisi datar. Jurnal Mitra Pendidikan, $2(1), 63-75$. 
Nadjafikhah, M., \& Yaftian, N. (2013). The frontage of creativity and mathematical creativity. Procedia - Social and Behavioral Sciences. https://doi.org/10.1016/ j.sbspro.2013.07.101

National Council Of Teachers Of Mathematics. (2000). Principles and standards for school mathematics. School Science and Mathematics. https://doi.org/10.1111/j.1949-8594.2001.tb17957.x

Pertiwi, A. D., \& Susilo, B. E. (2014). Analisis kemampuan komunikasi matematis melalui pembelajaran model 4k berdasarkan tipe kepribadian peserta didik kelas VII. Jurnal Kreano, 5(2), 195-204.

Praherdhiono, H., Setyosari, P., Degeng, I. N. S., Slamet, T. I., Surahman, E., Adi, E. P., Abidin, Z. (2019). Teori dan implementasi teknologi pendidikan: Era belajar abad 21 dan revolusi industri 4.0. Malang: Seribu Bintang.

Purnomo, D., \& Bekti, S. (2017). Patterns change of awareness process, evaluation, and regulation on mathematics student . International Electronics Journal of Mathematics Education (IEJME) Volume 12, Issue 7, October 2017. p-ISSN: 13063030, p-ISSN: 2468494

Redhana, I. W. (2019). Mengembangkan keterampilan abad ke-21 dalam pembelajaran kimia. Jurnal Inovasi Pendidikan Kimia, 13(1), 2239-2253.

Rifqiyana, L., \& Susilo, B. E. (2016). Analisis kemampuan berpikir kritis siswa kelas viii dengan pembelajaran model 4k ditinjau dari gaya kognitif siswa. Unnes Journal of Mathematics Education.

Rochmad, Kharis, M., Agoestanto, A., Zahid, M. Z., \& Mashuri. (2018). Misconception as a critical and creative thinking inhibitor for mathematics education students. Unnes Journal of Mathematics Education. https://doi.org/10.15294/ ujme.v7i1.18078

Sulistyorini, Y., \& Napfiah, S. (2019). Persepsi Mahasiswa terhadap 4K dalam pembelajaran matematika. Jurnal Matematika dan Pendidikan Matematika, 4(1), 73-86.

Vale, I., \& Barbosa, A. (2017). The importance of seeing in mathematics communication. Journal of the European Teacher Education Network.

van Roekel, D. (2014). Preparing 21 st century students for a global society: An educator's guide to the "four Cs ."National Education Association.

Victor, T. (2015). The challenges and opportunities of developing the 4c's in the math classroom. Retrieved March 4, 2019, from http://math.nie.edu.sg/ame/ amesms15/download/K5.pdf

Wijaya, L., Rochmad, \& Agoestanto, A. (2016). Analisis kemampuan berpikir kreatif matematis siswa smp kelas vii ditinjau dari tipe kepribadian. Unnes Journal of Mathematics Education., 5(2). https://doi.org/10.15294/ujme.v5i2.11401

Yuniar, Siti Nastiti., Sunardi., \& Kurniawati, D. (2017). Pengembangan indikator 4c's yang selaras dengan kurikulum 2013 SMA Kelas X Pada Materi Trigonometri. Kadikma, 8(3), 173-185.

Yuniarti, Y. (2016). Pengembangan kemampuan komunikasi matematis dalam pembelajaran matematika di sekolah dasar. Edu Humaniora| Jurnal Pendidikan Dasar Kampus Cibiru. https://doi.org/10.17509/eh.v6i2.4575

Zubaidah, S. (2010). Pembelajaran kolaboratif dan group investigation (Sebagai Salah Satu Teknik Pembelajaran Kolaboratif). Disampaikan dalam. Seminar Nasional Pembelajaran Biologi dengan 
Tema "Pengembangan Kemampuan Profesionalisme Guru melalui Pembelajaran Inovatif. Riau: Universitas Islam Riau. 